\title{
FEATURES OF THE NOTION OF WEAPONS IN THE CRIMINALISTICAL SCIENCE ON WEAPONS
}

\author{
Terehovich $V$. N., Nimande E. V.
}

The notion of the weapon and its individual variations are used in the norms of the criminal law or as the subject of a criminal act composition or as a qualifying attribute of a criminal act objective side, or as an optional feature of a criminal act composition objective side. By its essence, weapon is a kind of labor instruments whose structural features and method of use were defined by the need to protect and attack. The term "weapon» is used in various fields of knowledge and human activities. However, each of these areas of using notion "weapon» puts its importance into this notion. Definition of weapons used in military and technical disciplines does not clearly enough give an idea about the subjects which are summarized in the criminalistic notion of «weapons». The term «weapon» as an element of criminal law framework is the subject whose structural peculiarities and technical condition may actually facilitate causing serious and fatal injuries to man by them. The paper describes the criminalistic notion formation features on weapons from the position of the contemporary ideas of criminalistical science on weapons and practice of criminal acts investigation. It reveals the need and essence of concretizing signs of weapons criminalistic notion. As a basis for concretization of weapons notion is taken an encyclopedic notion, i. e., weapon is a tool designed for attack and defense. Concretization of this concept is carried out by cross-classification of weapons notion on two grounds - on the technical condition and the number of people which is necessary for working with a weapon. This cross-classification serves as a logical basis for the criminalistical definition of weapons. Thus, in criminalistic science on weapons a weapon is recognized only an individual weapon whose technical condition allows to realize its combating qualities.

Keywords: criminal law enforcement, investigation of criminal acts, criminalistical science on weapons, object of cognition of criminalistical science on weapons.

В. О. Малярова, професор кафедри криміналістики та судової експертології Харківського національного університету внутрішніх справ, доктор юридичних наук, доцент

\section{АКТУАЛЬНІ ПИТАННЯ АЛГОРИТМІЗАЦІї РОЗСЛІДУВАННЯ ОКРЕМИХ ВИДІВ ЗЛОЧИНІВ}

Розглянуто питання щзодо криміналістичного алгоритму розслідування як гнучкої системи науково розроблених і формалізованих приписів послідовного виконання в певному порядку оптимальних варіантів слідчих (розшукових) дій, негласних слідчих (розшукових) дій, оперативно-пошукових заходів та інших дій, об'єднаних задумом ефективного вирішення проміжних завдань розслідування злочину з урахуванням відповідних типових слідчих ситуацій. Надано авторське бачення алгоритму пошуку невідомого злочиния як послідовного вирішення конкретних завдань розслідування.

Ключові слова: пошукова діяльність слідого; установлення особи, яка вчинила злочин; алгоритм пошуку невідомого злочинияя.

(C) Малярова В. О., 2016 
Згідно зі ст. 2 Кримінального процесуального кодексу України одним із завдань кримінального провадження $\epsilon$ «...забезпечення швидкого, повного та неупередженого розслідування і судового розгляду з тим, щоб кожний, хто вчинив кримінальне правопорушення, був притягнутий до відповідальності в міру своєї вини...» ${ }^{1}$.

Відповідно до Закону України «Про Національну поліцію» до основних повноважень поліції, крім іншого належить покладене на неї завдання щодо розшуку осіб, які переховуються від органів досудового розслідування, слідчого судді, суду, ухиляються від виконання кримінального покарання та ін. (п. 7 ч. 1 ст. 23$)^{2}$. Одним із серйозних недоліків чинного кримінального процесуального законодавства $€$ відсутність прямої вказівки законодавця на необхідність розкриття злочину, тобто на пошук і встановлення особи, яка його вчинила. Адже процес розслідування злочину закономірно й логічно повинен призвести до встановлення істини в кримінальному провадженні, а отже, і до встановлення особи злочинця. Без цього неможливе швидке, повне й неупереджене розслідування та судовий розгляд. Тобто неможливе вирішення завдань кримінального провадження. Можна констатувати, що ця прогалина в законодавстві України вже сьогодні вкрай негативно позначається на загальному рівні розкриття злочинів, і серед багатьох інших факторів сприяє різкому погіршенню криміногенної обстановки в країні.

Безумовно, що пошук злочинців та в подальшому їх затримання сприяють швидкому, повному й неупередженому розслідуванню кримінальних проваджень, а недоліки пошукової діяльності слідчого негативно впливають на загальнодержавний рівень боротьби зі злочинністю. Ось чому проблемам пошуку злочинця приділяється багато уваги в криміналістиці. Установлення в процесі доказування особи, котра вчинила злочин, повинне бути одним із центральних завдань досудового розслідування. Вирішення цього завдання пов'язане 3 подоланням певних труднощів, особливо тоді, коли злочинцю вдалося втекти з місця злочину. Особу, яка вчинила злочин, можна вважати встановленою, якщо в слідчого $є$ дані, що дозволяють індивідуалізувати й ототожнити певну особу. Відомості про особу злочинця як об'єкт пошуку формуються в результаті дії закономірностей виникнення криміналістичної інформації. Процес установлення чи пошуку невідомого злочинця доцільно розглядати як алгоритм пошукової діяльності слідчого.

Метою розслідування будь-якого виду злочинів $є$ встановлення істини в кримінальному провадженні. Досягнення цієї мети можливе лише в тому разі, якщо слідчий вчасно вибере найоптимальніший шлях пізнання злочину на основі інформації, яку він має на початковому етапі розслідування, після внесення інформації до Єдиного реєстру досудових розслідувань (СРДР).

Практична реалізація такого напряму вбачається вченими у створенні програмно-цільового методу розслідування конкретних видів злочинів, що знаходить своє відображення в розробленні спеціалізованих програм роз-

\footnotetext{
${ }^{1}$ Кримінальний процесуальний кодекс України. - Х. : Право, 2012. - С. 3.

2 Див.: Закон України «Про Національну поліцію». — Х. : Право, 2015. — С. 14.
} 
слідування, алгоритмів процесу розслідування окремих видів злочинів або проведення конкретних слідчих (розшукових) дій ${ }^{1}$.

Питання алгоритмізації розслідування піддаються найретельнішому вивченню, підсумком якого стала розробка нових типових програм (алгоритмів) розслідування окремих видів злочинів, типових програм проведення окремих слідчих (розшукових) дій, а також наукових і практичних основ застосування таких програм (алгоритмів) як у ручному, так і машинному варіанті, тобто із застосуванням ЕОМ та ін.

Програмування можна визначити як метод раціоналізації розслідування й оптимізації його планування, зміст якого становлять програми, спрямовані на визначення наявної ситуації, з’ясування завдань розслідування та обрання засобів їх досягнення² .

Слід зауважити, що серед учених не існує єдності думок щодо назви як самого методу (програмно-цільовий, програмування, алгоритмізація), так і приписів, що становлять його зміст (програма, алгоритм) ${ }^{3}$. Ці терміни грунтуються на кібернетичній термінології. Отже, в інформатиці під алгоритмом розуміють точний припис, що визначає обчислювальний процес, який веде від вихідних даних до шуканого результату. Програма ж являє собою опис алгоритму мовою програмування. 3 огляду на те, що в криміналістичній літературі, розкриваючи проблему алгоритмізації розслідування, автори подають точну систему дій, зорієнтованих на типові слідчі ситуації того або іншого етапу розслідування залежно від виду злочинного діяння, уявляється правильним використання терміна «алгоритм». При цьому метод оптимізації процесу розслідування доцільно назвати алгоритмізацією ${ }^{4}$.

У криміналістичній діяльності стосовно розслідування злочинів алгоритмізація - це формалізована діяльність слідчого, прокурора й інших осіб за допомогою мови логіки висловлення, що являє собою компонент мето-

${ }^{1}$ Див.: Курс криминалистики : Особенная часть. Т. 1: Методики расследования насильственных и корыстно-насильственных преступлений / отв. ред. В. Е. Корноухов. - М. : Юристь, 2001. - С. 12-19.

2 Див.: Зорин Г. А. Криминалистическая методология : науч.-популяр. изд. / Г. А. Зорин. - Минск : Амалфея, 2000. — С. 145-146.

${ }^{3}$ Див.: Густов Г. А. Программно-целевой метод организации раскрытия убийств : конспект лекций / Г. А. Густов. - Л. : ЛГУ, 1985. - С. 6-7, 145-146; Матусовский Г. А. Возможности разработки и применения в целях расследования типовых схем признаков хищений и программ для ЭВМ / Г. А. Матусовский, А. А. Дудников // Проблемы совершенствования расследования и профилактика преступлений на современном этапе. - Уфа : Изд-во Башкир. гос. ун-та, 1990. — С. 129-130; Цветков С. И. Перспективы использования ЭВМ для алгоритмизации преступлений на современном этапе / С. И. Цветков, Е. П. Ищенко. — Уфа : Изд-во Башкир. гос. ун-та, 1990. - C. 26.

4 Див.: Турчин Д. А. Система следов как алгоритм действий следователя / Д. А. Турчин // Алгоритмы и организация решений следственных задач. - Иркутск : Изд-во Иркут. ун-та, 1982. - С. 36-37; Томш В. Г. Подходы к разработке алгоритма поведения сотрудника ОВД в условиях многолюдности / В. Г. Томш, Ю. Н. Черторицкий // Алгоритмы и организация решений следственных задач. - Иркутск : Изд-во Иркут. ун-та, 1982. - С. 92-97. 
дики вирішення криміналістичних завдань ${ }^{1}$. Алгоритмізація дозволяє перетворити цей процес із діяльності слабко контрольованої на діяльність програмно-керовану, підвищити об'єктивність іiі результатів, створити реальні передумови для автоматизованого оброблення інформації.

Алгоритмізацію розслідування можна розглядати як творчий процес створення формалізованої моделі діяльності слідчого щодо вирішення завдань розслідування злочину у вигляді алгоритму, практичне використання якого сприяє оптимізації зазначеної діяльності й підвищенню ії ефективнос$\mathrm{Ti}^{2}$. Важливою передумовою успішного здійснення алгоритмізації слідчої діяльності з розслідування злочинів є розроблення типових алгоритмів розслідування окремих видів злочинів і проведення слідчих (розшукових) дій.

Криміналістичний алгоритм розслідування - це гнучка система науково розроблених і формалізованих приписів послідовного виконання в певному порядку оптимальних варіантів слідчих дій, оперативно-пошукових заходів та інших дій, об'єднаних задумом ефективного вирішення проміжних завдань розслідування злочину з урахуванням відповідних типових слідчих ситуацій ${ }^{3}$.

3 пізнавальної точки зору вихідним у процесі встановлення невідомого злочинця $є$ визначення проміжних завдань, відповідних їм методів і суб' єктів, що ведуть до вирішення кінцевого завдання. Теоретичною основою пошукової діяльності слідчого є положення окремих вчень криміналістики: теорій ідентифікації та діагностики.

Алгоритм пошуку невідомого злочинця включає послідовне вирішення таких завдань:

1) виявлення джерел інформації про ознаки невідомого злочинця;

2) побудова гіпотетичної моделі особи злочинця та встановлення його належності до:

- широкої сукупності (класу) осіб за загальними ознаками;

- вузької сукупності (групи) осіб за окремими ознаками;

3) установлення обмеженої, кількісно визначеної групи осіб, що перевіряються;

4) установлення особи, що перевіряється, тобто особи, яка згідно з обставинами кримінального провадження може бути невідомим злочинцем, і за необхідності отримання від неї зразків для експертизи відповідно до ст. 245 КПК України;

5) ідентифікація конкретної особи;

6) установлення невідомого злочинця.

1 Див.: Быховский И. Е. Программирование расследования: возможности и перспективы / И. Е. Быховский // Актуальные проблемы советской криминалистики. — М. : Юрид. лит., 1980. - С. 63.

2 Див.: Асташкина E. Н. Криминалистические алгоритмы в расследовании квартирных краж : учеб. пособие / Е. Н. Асташкина, Н. А. Марочкин. - М. : Юрлитинформ, 2003. - С. 12.

3 Див.: Малярова В. О. Тактико-криміналістичні та процесуальні основи пошуку та затримання злочинця : дис. ... канд. юрид. наук : 12.00 .09 / В. О. Малярова. - X., 2005. - 238 c. 
На початкових етапах (завдання 1-3) найбільш широко використовуються методи діагностичних досліджень, метою яких $є$ віднесення невідомого злочинця (особи, що ідентифікується) до все вужчих класифікаційних сукупностей за допомогою стаціонарних і спеціально створених класифікацій. Установлення обмежених класів і груп є важливим при організації пошукових заходів (завдання 4). Після визначення кола осіб, що перевіряються, настає етап ототожнення (завдання 5). Злочинець установлюється за результатами ідентифікації (завдання 6). При цьому кожне наступне завдання випливає з попереднього i, як правило, не може бути розв'язане без вирішення попереднього.

Докладніше розглядаючи наданий алгоритм, можна констатувати, що кожне із шести проміжних завдань алгоритму пошуку невідомого злочинця передбачає конкретні, властиві цьому проміжному завданню дії.

Проміжне завдання № 1. Виявлення матеріальних та ідеальних джерел інформації про злочин і злочинця. Це $є$ основою для вирішення ідентифікаційно-пошукових завдань. Сліди шуканого злочинця, що відображають його властивості, слугують первісною ідентифікаційною інформацією про особу, яка пов'язана з розслідуваною подією.

Проміжне завдання № 2. На основі властивостей невідомого злочинця, що встановлені за залишеними слідами, початкове завдання його пошуку визначається як перехід від установлення невизначено широких сукупностей (класів) осіб до встановлення їх вузьких, якісно визначених сукупностей (груп), тобто вихідної сукупності. Установити належність невиявленого злочинця до класу або групи осіб - означає скласти уявлення про те, до якої сукупності (вікової, статевої, расової, національної, професійної та ін.), якої соціальної категорії, якої верстви населення він належить ${ }^{1}$. Вирішення цього завдання навіть на рівні побудови гіпотетичної моделі злочинця дозволяє окреслити коло осіб, серед яких він може перебувати. При цьому вихідну сукупність можна визначити як мінімальну множину, коло шуканих осіб, виділених на основі вихідної ідентифікаційної інформації, що міститься в слідах злочину.

В основу визначення групової належності злочинця може бути покладене достовірне знання про яку-небудь його ознаку (ознаки), коли $є$ відповідні докази, а також можливе (імовірне) знання, яке випливає з аналізу даних про спосіб, мотив учинення злочину тощо. Формований комплекс пошукових ознак може бути комбінованим і включати встановлені й передбачувані ознаки. Зазвичай первинні дані дозволяють скласти уявлення про досить велике коло людей, які підлягають перевірці. Після чого виникає завдання забезпечити конкретизацію вихідної множини об'єктів, що перевіряються. 3 цією метою проводиться класифікація, поділ зазначеної множини на групи, підгрупи інших, невідомих ознак злочинця.

Установлення класу здійснюється на основі технічних, природничо-наукових стаціонарних класифікацій, створених поза зв'язком із розслідуваною

${ }^{1}$ Див.: Образияов B. А. Криминалистика: модели средств и технологий раскрытия преступлений : курс лекций / В. А. Образцов. - М. : ИМПЭ-ПАБЛИШ, 2004. C. 296. 
подією, а підставами класифікацій виступають загальні ознаки осіб. Характерними рисами такого дослідження з метою класифікації є: а) одержання вихідної інформації за слідами невідомого злочинця; б) використання еталонів різних класифікаційних груп (наприклад, зразків крові), а також описів їх властивостей у картотеках, каталогах, довідниках тощо (наприклад, опис зовнішності); в) порівняння виявлених слідів і еталонів (описів) за класифікаційними ознаками, виділеними до початку дослідження; г) установлення мінімального за обсягом класу, що обов'язково містить шукану особу.

Як правило, слідчий може встановити лише відносно широкі класифікаційні групи, а подальше визначення найвужчої сукупності вимагає залучення спеціалістів. Звуженню кола осіб, які перевіряються, сприяє одержання даних про нові, до цього невідомі ознаки злочинця, і включення їх до ознак гіпотетичної уявної моделі особи злочинця, виключення з таких груп осіб, для яких ці ознаки не характерні.

Після того, як можливості стаціонарних класифікацій вичерпані, подальша індивідуалізація цієї особи здійснюється шляхом накопичення ознак, що використовуються для формування спеціальних (нестаціонарних) класів. Для їх утворення можуть бути використані не всі ідентифікаційні властивості або окремі ознаки особи, а тільки ті, які добре виражені й достатньо стійкі в ідентифікаційний період, наприклад «особливі прикмети». Зрозуміло, що чим більша кількість специфічних, добре виражених і стійких ідентифікаційних властивостей була використана для формування нестаціонарної класифікації, тим таке обмеження буде значнішим для розслідування. Слідчий, застосовуючи метод обмеження, виходячи з обставин кримінального провадження, виділяє зі складу зазначеного класу більш вузьку групу осіб.

Проміжне завдання № 3. Установлення обмеженої, кількісно визначеної групи осіб, що перевіряються (до якої належить невідомий злочинець), здійснюється двома взаємозалежними методами: а) методом обмеження, який полягає у встановленні об'єктивного зв’язку осіб, що входять у групу, з розслідуваною подією; б) методом виключення, який полягає в тому, що порівняльне дослідження здійснюється 3 метою послідовного виключення основної маси осіб, які входять у групу, що перевіряється, а особи, які залишилися, піддаються всебічному ідентифікаційному аналізу. Якщо коло осіб, котрі перевіряються, установлене та чітко обмежене, застосування методу виключення може виявитися достатнім для встановлення конкретної особи й вирішення завдань доказування ${ }^{1}$.

Застосування методу виключення вимагає тісного зв’язку слідчих і експертних методів доказування, а необхідна для встановлення невідомої особи інформація повинна включати: а) дані, котрі вичерпним чином установлюють коло осіб, які перевіряються; б) підстави виключення всіх осіб, котрі перевіряються, крім однієї; в) збіг ідентифікаційних властивостей шуканого та не виключеного об'єкта, що перевіряється; г) дані, котрі вказують на зв'язок особи з подією злочину.

${ }^{1}$ Див.: Малярова В. О. Указ. праця. 
За відсутності хоча б однієї із зазначених інформаційних підсистем невідома особа не може вважатися достовірно встановленою.

Проміжне завдання № 4. Версія про зв'язок конкретної особи, яка перевіряється, з розслідуваною подією може мати дві підстави: ідентифікаційну (коли має місце збіг ідентифікаційних ознак) і ситуаційну (коли при аналізі слідчої ситуації особа, котра перевіряється, розглядається як одна із можливих учасниць розслідуваної події).

Особа, яка перевіряється, - це модель особи невідомого злочинця, спочатку інформаційно-логічна (версія), а потім і матеріальна (з моменту виявлення відповідної особи). Моделювання особи невідомого злочинця 3 урахуванням ситуації вчинення злочину дозволяє встановити напрямок відображення іiі властивостей, їх характер і природу. Воно дає змогу попередньо визначити об'єкт, що ідентифікується, а також зміст роботи з отримання зразків для експертизи (ст. 245 КПК України).

Попереднє моделювання особи невідомого злочинця має різне функціональне призначення: 1) забезпечує отримання зразків для експертизи; 2) дозволяє відокремлювати пов'язані зі злочином сліди від іншої нейтральної інформації, що розглянута в динамічній системі інших елементів розслідуваної події; 3) допомагає вирішити важливе для слідчої та судової практики питання стосовно відомостей про обставини злочину, що мають значення для проведення експертизи, а тому повинні повідомлятися експерту слідчим; 4) з урахуванням слідчої ситуації полегшує перевірку й оцінювання результатів ідентифікації при сукупному оцінюванні зібраних доказів. Ефективним методом при цьому є моделювання розслідуваної події «за участю» шуканої особи, яке здійснюється у формі слідчого експерименту, шляхом відтворення дій, обстановки, обставин певної події, проведення необхідних дослідів чи випробувань (ст. 240 КПК України).

Установлення особи, котра перевіряється, як інформаційної й предметної моделі особи невідомого злочинця, $є$ важливим інструментом доказування, що забезпечує правильне орієнтування слідчого (експерта) в обставинах розслідуваного злочину, цілеспрямований пошук злочинця, ефективне отримання зразків для експертизи, перевірку й оцінювання результатів ідентифікації в системі зібраних доказів у кримінальному провадженні.

Проміжне завдання № 5. У разі наявності сліду невідомого злочинця та зразків від особи, яка перевіряється, може бути виконане порівняльне дослідження з метою вирішення питання про тотожність, тобто ідентифікація. Завдання встановлення особи, котра ідентифікується, вирішується на основі всієї суми інформації про невідомого злочинця, яка міститься в сукупності залишених слідів.

Проміжне завдання № 6. Невідомий злочинець установлюється на основі виявлення зв'язку ідентифікованої особи з обставинами вчинення злочину.

Кожне з проміжних завдань, поставлених з метою встановлення невідомого злочинця, вирішується конкретними суб'єктами з використанням двох груп методів: перша група методів (завдання 2-5) застосовується для індивідуалізації особи, друга група методів - для встановлення зв'язку особи з розслідуваною подією (завдання 6). 
Установлення обмежених класів і груп об’єктів є дуже важливим для організації пошукових заходів, у той час як обмеження вихідної сукупності відіграє суттєву роль у визначенні критеріїв оцінювання сукупності ознак, необхідних для встановлення тотожності.

Класифікаційні дослідження, які вимагають знання загальнонаукових і спеціальних класифікацій, методики виявлення й оцінювання ознак, застосування спеціального устаткування та науково-технічних засобів, пов’язані з необхідністю залучення відповідних спеціалістів. Застосування ж методу обмеження грунтується на аналізі обставин кримінального провадження, механізму розслідуваної події, а тому може бути здійснене лише слідчим. До компетенції слідчого належать констатація ситуації індивідуального визначення, побудова версій про шуканий об'єкт, дослідження його зв’язку з подією злочину. Усі ці методи засновані на аналізі механізму розслідуваної події та окремої системи фактичних даних про шуканий об'єкт.

Отже, установлення в процесі розслідування особи, яка вчинила злочин, повинно бути одним із центральних завдань досудового розслідування в кримінальному провадженні. Його вирішення виявляє значні труднощі, особливо коли злочинцю вдалося зникнути з місця події. Потреби сучасної слідчої практики свідчать, що назріла гостра необхідність дослідження наукових і прикладних проблем пошуку й установлення особи злочинця для забезпечення швидкого, повного та неупередженого розслідування й судового розгляду справи.

\section{АКТУАЛЬНЫЕ ВОПРОСЫ АЛГОРИТМИЗАЦИИ РАССЛЕДОВАНИЯ ОТДЕЛЬНЫХ ВИДОВ ПРЕСТУПЛЕНИЙ}

\section{Малярова В. $\boldsymbol{O}$.}

Рассмотрены вопросы криминалистической алгоритмизации расследования как гибкой системы формализованных научных предписаний по последовательному выполнению оптимальных вариантов следственных (розыскных) действий, негласных следственных (розыскных) действий и оперативно-розыскных мероприятий, для эффективного решения промежуточных задач расследования преступления с учетом соответствуюших типовых следственных ситуаций. Представлено авторское видение алгоритма розыска (установления) неизвестного преступника как последовательного решения конкретных задач расследования.

Ключевые слова: поисковая деятельность следователя; установление лица, совериившего преступление; алгоритм розыска неизвестного преступника.

\section{ACUTE ISSUES OF ALGORITHMIZATION OF CERTAIN TYPES OF CRIMES INVESTIGATION}

\section{Maliarova $\boldsymbol{V}$. $\boldsymbol{O}$.}

The strategic purpose of crime investigation is to establish truth in a criminal case. Achieving this goal is possible only if the investigator chooses the optimum way of crime cognition on the basis of available information. The practical realization of this direction is seen by scientists in creating program-target methods of investigation for certain types of crime, which are reflected in the development of specialized programs. Algorithmization 
of investigation is considered in the article as a creative process of building formal models of investigator activity to address the specific problems of pre-trial investigation. In practice the use of such an algorithm helps to optimize and improve the efficiency of investigator activity. At the same time an important prerequisite for the successful implementation of investigative activity algorithmization is the development of typical algorithms for the investigation of certain types of crimes and carrying out investigatory (search) operations. The author considers criminalistic algorithmization of investigation as a flexible system of formal scientific requirements for consistent realization of the best options of investigative (search) activities, covert investigative (search) actions and operational and search measures to effectively address the interim objectives of the investigation with regard to the relevant typical investigative situations. The article presents the author's vision of algorithm of an unknown criminal search (identification) as a consistent solution of specific problems of the investigation. The author emphasizes that one of the major shortcomings of the current criminal procedural legislation is the absence of direct indication of the legislator to the need to identify the person who committed the crime. The process of crime investigation should naturally and logically lead to the establishment of the truth in a criminal proceeding and therefore to criminal personality identification.

Keywords: search activity of investigator; identification of a person who committed a crime; algorithm of unknown criminal search.

B. B. Білоус, доцент кафедри криміналістики Національного юридичного університету імені Ярослава Мудрого, кандидат юридичних наук, доцент

\section{КЛАСИФІКАЦІЯ БЕЗПІЛОТНИХ ЛІТАЛЬНИХ АПАРАТІВ ТА ЇЇ ЗНАЧЕННЯ ДЛЯ КРИМІНАЛІСТИЧНОЇ ПРАКТИКИ}

3'ясовано поняття та розроблено узагальнену класифікацію безпілотних літальних апаратів. Обгрунтовано необхідність урахування запропонованої класифікаиї̈ при формулюванні криміналістичних вимог до тактико-технічних даних безпілотних літальних апаратів і систем, безпілотних авіачійних комплексів та характеристик їх иільового спорядження, дотримання яких найбільше відповідатиме задоволенню актуальних потреб польової криміналістики.

Ключові слова: криміналістична техніка, інформаційні технології, безпілотні літальні апарати й системи, безпілотні авіаційні комплекси, класифікація безпілотних літальних апаратів.

У Стратегії розвитку вітчизняної авіаційної промисловості на період до 2020 р. зафіксовано відомий факт про те, що Україна належить до небагатьох держав, які володіють повним циклом створення авіаційної техніки, і займає значне місце на світовому авіаційному ринку в секторі транспортної та регіональної пасажирської авіації. Результати дослідження потенціалу підприємств авіаційної промисловості свідчать про цілком можливе збільшення обсягів розроблення й виробництва авіаційної техніки, зокрема за такими

(C) Білоус В. В., 2016 